\section{Formation of Polymeric Carbon Suboxide during Gamma Radiolysis of Liquid Carbon Monoxide at $77^{\circ} \mathrm{K}$}

Buschmann and Groth ${ }^{1}$ have reported tho formation of carbon dioxide during gamma radiolysis of liquid carbon monoxide at $77^{\circ} \mathrm{K}$ and have estimated that $\mathrm{G}\left(\mathrm{CO}_{2}\right)=0 \cdot 18$. These authors detected the formation of a carbonaceous deposit which on heating evolved only small quantities of $\mathrm{CO}_{2}$; they therefore suggested that the deposit was largely composed of solid carbon.

We wish to report experimental data which indicate that the carbonaceous deposit formed during radiolysis of liquid carbon monoxide at $77^{\circ} \mathrm{K}$ is polymerized carbon suboxide. Furthermore, our results indicate that the reaction stoichiometry in the liquid phase at $77^{\circ} \mathrm{K}$ is the same as that in the gas phase at 1 atm. and $295^{\circ} \mathrm{K}$.

Carbon monoxide, free of oxygen and other impurities, was prepared as described by Clay et $a l .^{2}$. Irradiations were carried out on a 17,000 $\mathrm{Ci}$ source of cobalt- 60 . Dose rates were determined by ferrous sulphate dosimetry. The silica reaction vessel, about $3 \mathrm{~cm}^{3}$ capacity, had a long fine bore neck ( $25 \mathrm{~cm}$ long, $0 \cdot 3 \mathrm{~cm}$ internal diameter) which terminated on a 'Pyrex' glass vacuum stopcock with a $B 10$ cone-socket connexion. A water cooled jacket, $7 \mathrm{~cm}$ long, below the $B 10$ connexion, and an asbestos thermal radiation shield below the water jacket, prevented pyrolysis and oxidation of the tap grease during analysis. Product gases were transferred by means of a single stage diffusion pump and a Toepler pump, to a gas burette. The yields were determined by PVT moasurement. $\mathrm{CO}_{2}$ formed during irradiation was separated from the unreacted $\mathrm{CO}$ by passing the contents of the vessel through a spiral trap the lower half of which was refrigerated with liquid oxygen. The solid formed during irradiation was first vacuum pyrolysed at $1,000^{\circ} \mathrm{C}$, the $\mathrm{CO}$ and $\mathrm{CO}_{2}$ formed being fractionated in the trap. The carbon remaining after pyrolysis was burnt to $\mathrm{CO}_{2}$ by adding excess $\mathrm{O}_{2}$ to the vessel and heating.

Table 1. GAMMA RADIOLYSIS OF LIQUID CARBON MONOXIDE AT $77^{\circ} \mathrm{K}$, ANAIYYSIS OF REACTION PRODUCTS

\begin{tabular}{|c|c|c|c|c|c|}
\hline $\begin{array}{l}\text { Fxperi- } \\
\text { ment }\end{array}$ & $\begin{array}{l}\text { Total dose } \\
\left(\mathrm{eV} \times 10^{-30}\right)\end{array}$ & $\begin{array}{c}\text { Radiolytic } \\
\mathrm{CO}_{2} \text { yield } \\
\left(\text { moles }^{2} 10^{6}\right)\end{array}$ & $\begin{array}{l}\text { Vacuum } \\
\text { analysis } \\
\text { CO yield } \\
\text { (moles } \times 10^{\circ}\end{array}$ & $\begin{array}{l}\text { yrolytic } \\
\text { product } \\
\mathrm{CO}_{2} \text { yield } \\
\left(\text { moles }^{2} 10^{8}\right)\end{array}$ & $\begin{array}{c}\text { Burn off of } \\
\text { residual } \\
\text { deposit: } \mathrm{CO}_{2} \\
\text { yield } \\
\left(\text { moles } \times 10^{8}\right)\end{array}$ \\
\hline $\begin{array}{l}1 \\
2 \\
3 \\
4 \\
5\end{array}$ & $\begin{array}{l}2 \cdot 68 \\
5 \cdot 10 \\
7 \cdot 85 \\
21 \cdot 1 \\
31\end{array}$ & $\begin{array}{r}1 \cdot 11 \\
2 \cdot 14 \\
3 \cdot 00 \\
8 \cdot 15 \\
11 \cdot 5\end{array}$ & $\begin{array}{c}0.93 \\
1.55 \\
1.81 \\
6.20 \\
10.0\end{array}$ & $\begin{array}{l}0 \cdot 61 \\
1 \cdot 08 \\
1 \cdot 62 \\
4 \cdot 4 \\
5 \cdot 25\end{array}$ & $\begin{array}{c}1 \cdot 95 \\
2 \cdot 82 \\
4 \cdot 00 \\
11 \cdot 3 \\
14 \cdot 0\end{array}$ \\
\hline
\end{tabular}

Dose rate, $2.86 \times 10^{17} \mathrm{eV} \mathrm{g}^{-1} \mathrm{~min}^{-1}$.

Table 1 shows the result of the analysis. $\mathrm{G}\left(\mathrm{CO}_{2}\right)$ estimated from these data is $0.24 \pm 0.01$ molecules per $100 \mathrm{eV}$-about 25 per cent higher than that previously reported ${ }^{1}$.

If the reaction stoichiometry is

$$
4 n \mathrm{CO} \leadsto \rightarrow n \mathrm{CO}_{2}+\left(\mathrm{C}_{3} \mathrm{O}_{2}\right)_{n}
$$

then the $\mathrm{C}: \mathrm{O}$ ratio for all the reaction products is unity and the $\mathrm{C}: \mathrm{O}$ ratio for the solid is $1 \cdot 5$. These two ratios ealculated from the experimental results are shown in Table 2.

Table 2. GAMMA RADIOLYSIS OF LIQUID CARBON MONOXIDE AT $77^{\circ} \mathrm{K}$, MASS BALANOE AND SOLID COMPOSITION RATIOS CALCULATED FROM THE DATA

\begin{tabular}{|c|c|c|}
\hline Wxperiment & $\frac{x}{y}$ on $\mathrm{C} x \mathrm{O} y$ & $\begin{array}{l}\text { C in products } \\
o \text { in products }\end{array}$ \\
\hline $\begin{array}{l}1 \\
2 \\
3 \\
4 \\
5\end{array}$ & $\begin{array}{l}1.62 \\
1.48 \\
1 \cdot 43 \\
1 \cdot 62 \\
2 \cdot 2\end{array}$ & $\begin{array}{l}1.05 \\
0.96 \\
0.94 \\
1.10 \\
0.96\end{array}$ \\
\hline Average & $1.65 \pm 0.23$ & $0.96 \pm 0.03$ \\
\hline
\end{tabular}

The experimental data indicate that the solid has the composition $\left(\mathrm{C}_{3} \mathrm{O}_{2}\right)_{n}$ and that the overall stoichiometry is that discussed here and is identical to that reported by Anderson et al. ${ }^{3}$ for gamma and proton radiolysis of carbon monoxide gas at $1 \mathrm{~atm}$. and $295^{\circ} \mathrm{K}$. This result strongly contrasts with the finding of Buschmann and Groth ${ }^{1}$, who found that gamma radiolysis of pure liquid $\mathrm{CO}$ at $77^{\circ} \mathrm{K}$ results in the formation of $\mathrm{CO}_{2}$ and a solid deposit consisting chiefly of carbon. These authors were not able to reconcile this result satisfactorily with the observation that the addition of methane results in the formation of monomeric carbon suboxide. If our results are correct, formation of the solid deposit may be caused by the initial formation of monomoric $\mathrm{C}_{3} \mathrm{O}_{2}$ and its subsequent polymerization presumably by charge transfer from the primary ion $\mathrm{CO}^{+}$. Formation of $\mathrm{C}_{3} \mathrm{O}_{2}$ monomer on addition of methane can then be explained in terms of competi. tion between $\mathrm{C}_{3} \mathrm{O}_{2}$ and $\mathrm{CH}_{4}$ for $\mathrm{CO}^{+}$. It is no longer necessary to invoke the formation of two different carbon atom species in the system.

We thank the Science Research Council for a grant (to J.P. B.) and Professor G. R. Hall for his encouragement.

J. P. BRIGGS

P. G. CLAY

Department of Chemical Engineering and

Chemical Technology,

Imporial College, .

University of London.

Received March 13, 1968.

${ }^{1}$ Buschmann, H. W., and Groth, W., Z. Naturforsch., 22a, 954 (1967).

${ }^{2}$ Clay, P. G., Johnson, G. R. A., and Warman, J. M., Disc. Faraday Soc,, 36, 46 (i963).

${ }^{3}$ Anderson, A. R., Best, J. V. F., and Willett, M. J., Trans. Faraday soc., $62,595(1966)$.

\section{Sorption and Diffusion in Polymers}

IT has been suggested that the kinetics of water sorption by cellulose as well as the sorption kineties of other small penetrant molecule-polymer systems in the region where the polymer behaves like a glass can be explained in terms of a coupled diffusion-relaxation mechanism ${ }^{1-3}$. The sorption kineties have been studied with the original regenerated cellulose modified by a moderate degree of formaldehyde induced cross-linking.

A series of successive interval sorption measurements on the unmodified cellulose are illustrated in Fig. 1. These curves show the characteristic two-stage sorption, and estimates of the amounts sorbed in each stage are plotted as a function of relative vapour pressure in $A$ of Fig. 2. The upper curve is the sorption isotherm of total amount sorbed. The equivalent eurves for the treated cellulose are shown in $B$ of Fig. 2. The general character of the curves is the same although there are some significant differences between the two samples. The total amount sorbed for the untreated cellulose is greater than that for the treated cellulose and most of this difference seems to result from sorption in the second stage.

The water-cellulose type sorption isotherm is sometimes taken to be due to two "phases" of sorption 4 , and these "phases" seem to correspond to the initial and final stages. The initial stage could correspond to Langmuir ${ }^{5}$ unimolecular layer sorption and the second stage to multimolecular sorption; or the sigmoid shape of the sorption isotherm could be caused by swelling constraint ${ }^{6}$. For polymers at high enough temperatures, at which they behave like rubber, the isotherm corresponds to the Flory-Huggins ${ }^{7,8}$ theory, and this type of isotherm seems similar to the second stage curve of Fig. 2.

It would seem that the sorption isotherms and the anomalous kinetic behaviour in the glassy state are re- 